\title{
THE RIGHT TO VOTE:
}

\section{IMPLICATIONS OF NEW ZEALAND'S \\ INTERNATIONAL LEGAL OBLIGATIONS AND THE NeW ZEALAND BiLl OF Rights ACT 1990}

\author{
Sarah McClelland*
}

New Zealand now has a new electoral system, popularly known as "MMP" (mixed member proportional). This article challenges several aspects of the new electoral laws, and claims that they are not consistent with international obligations or with the right to vote set out in the New Zealand Bill of Rights Act 1990. The aspects covered are the rules relating to voting by prisoners, the residential requirements for voting, and the election of list MPs.

\section{INTRODUCTION}

In 1986 a Royal Commission into the electoral system produced its report. ${ }^{1}$ The recommendations of the Royal Commission relating to the franchise, in most respects became law in the Electoral Act 1993. But were all the issues concerning the significance of the franchise adequately dealt with by the Royal Commission and the 1993 Act? What issues can be expected to re-emerge in the future? In particular, did the Royal Commission and Parliament overlook and/or underestimate the implications of New Zealand's international legal obligations? The purpose of this article is to explore the significance of the franchise in relation to New Zealand's international obligations under the International Covenant on Civil and Political Rights and the New Zealand Bill of Rights Act 1990.

* This article is a chapter in a thesis submitted for an LLM degree at Victoria University of Wellington. The author would like to acknowledge the assistance of Antony Shaw, Lecturer in Law.

1 Report of the Royal Commission on the Electoral System: Towards A Better Democracy (Government Printer, Wellington, 1986). 
Article 21 of the Universal Declaration of Human Rights adopted by the General Assembly of the United Nations in 1948 states:

1. Everyone has the right to take part in the government of his country, directly or through freely chosen representatives.

2. ...

3. The will of the people shall be the basis of the authority of government; this will shall be expressed in periodic and genuine elections which shall be by universal and equal suffrage and shall be held by secret vote or by equivalent free voting procedures.

Subsequently, this guarantee was confirmed in the International Covenant on Civil and Political Rights which New Zealand ratified on 28 December 1978. Article 25 of the Covenant states:

Every citizen shall have the right and the opportunity, without any of the distinctions mentioned in article 2 and without unreasonable restrictions:

a) To take part in the conduct of public affairs, directly or through freely chosen representatives;

b) To vote and to be elected at genuine periodic elections which shall be by universal and equal suffrage and shall be held by secret ballot, guaranteeing the free expression of the will of the electors;

c) $\ldots$.

Section 12 of the Bill of Rights Act 1990 is designed to implement these international legal obligations: recital (b) to the long title states that it is "[a]n Act ...[t]o affirm New Zealand's commitment to the International Covenant on Civil and Political Rights". Section 12 provides that:

Every New Zealand citizen who is of or over the age of 18 years-

a) Has the right to vote in genuine periodic elections of members of the House of Representatives, which elections shall be by equal suffrage and by secret ballot; and

b) Is qualified for membership of the House of Representatives.

At present, the Bill of Rights Act 1990 has the status of an ordinary statute which can be overridden by other enactments: see s 4 of the Act. This raises serious questions about whether New Zealand law can be said to comply with New Zealand's international legal obligations, ${ }^{2}$ although there is a legal obligation on the Attorney-General under $\mathbf{s} 7$ of the Act to consider $\mathrm{s} 12$ when Parliament proposes to enact amendments to the electoral law.

2 See Re Bennett (1993) 2 HRNZ 358. For discussion, see below at heading F. 
This article analyses the impact of New Zealand's international legal obligations and of the Bill of Rights Act 1990 by focussing on the following issues:

1 The enfranchisement of prisoners.

2 The right to vote of citizens who reside overseas for a period of time.

3 The definition of a "genuine" election.

The reason for selecting these specific issues is that each highlights the interrelationships between the historical aspect of the franchise as a privilege with obligations attached, New Zealand's international obligations, and the application of the franchise as a "right" in a free and democratic society.

The implications of s 12(a), read together with s 5, of the Bill of Rights Act 1990 were considered prior to the enactment of the Electoral Act 1993. These provisions and the parallel provisions in the Canadian Charter of Rights and Freedoms will be discussed in some detail as the Charter's limitations provision ("reasonable limits prescribed by law as can be demonstrably justified in a free and democratic society") is identical to the limitations provision contained in $\mathbf{s} 5$ of the Bill of Rights Act and equates with the Covenant's "unreasonable restrictions" provision in article 25.

It is convenient to begin with the Royal Commission's report. It is remarkable that the Royal Commission in its report did not consider the impact of New Zealand's treaty obligations under article 25 of the Covenant. At no point does the Report refer to or consider these obligations. This is a deficiency, which leads to the conclusion that the Report and its recommendations are flawed. ${ }^{3}$ What is worse, in relation to the issues stated above, the specific recommendations are reflected and enacted in the Electoral Act 1993. It is submitted that consideration of the obligations of the Covenant would have affected the Commission's recommendations.

3 The approach of the Royal Commission is in stark contrast to the approach of the (English) Law Commission in its Consultation Paper No 138 entitled Criminal Law Evidence in Criminal Proceedings: Hearsay and Related Topics (1995) para 5.1. "[The United Kingdom] has ... undertaken obligations in international law that it will conform in its domestic practice with the terms and principles of the [European] Convention. It follows that whenever it contemplates any particular measure of law reform the United Kingdom, and therefore this Commission, should do its best to ensure that any law which it proposes should be created or retained does indeed conform with the requirements of the Convention." Compare the requirements of the Cabinet Office Manual (1991) ch 5. 


\section{ENFRANCHISEMENT OF PRISONERS}

\section{A Background}

Prior to the Electoral Amendment Act 1975 enacted by the Labour Government, persons who were "detained pursuant to convictions in any penal institution" were disqualified to be registered as electors and were therefore unable to vote. ${ }^{4}$ Those whose names were on the Corrupt Practices List were similarly disqualified. ${ }^{5}$ The 1975 Amendment Act repealed the prisoners' disqualification provision and thus some 2000 prisoners were entitled to vote. $^{6}$ Those whose names where on the Corrupt Practices List remained disenfranchised. This disparity was clearly reflected in the speeches in Parliament by the National Opposition members who criticised any move to enfranchise prisoners as the Government taking a soft line on law and order. ${ }^{7}$

At the time, Mr J Pope, in an editorial in the New Zealand Law Journal, pointed out that by enabling prisoners to vote Parliament was acting logically and sensibly. ${ }^{8}$ Arguing from the premise that the right to vote was a fundamental right in a democracy, Mr Pope noted that New Zealand had in the past "practised the denial of democracy by refusing prison inmates the right to vote". ${ }^{9} \mathrm{He}$ continued: ${ }^{10}$

Prisoners they may be, but they still have rights and responsibilities, and if giving them the vote is to increase parliamentary appreciation of the prisoners' existence it can be no bad thing. Certainly an awareness that they are members of society is the very attitude our penal system is working to engender.

For the first time in New Zealand, all prisoners were entitled to vote at the 1975 general election. ${ }^{11}$ Electioneering in prisons was banned but lists of candidates and party manifestos were able to be displayed. Prisoners were also able to listen to party political broadcasts during normal prison radio and television time. Enrolment cards were distributed and booths set up. The fear of prisoner votes holding the balance of power in a

4 Section 42(1)(d) Electoral Act 1956.

5 Section 42(1)(c) Electoral Act 1956.

6 Evening Post, 15 October 1975, p 3.

7 (1975) 400 NZPD 3777, 3783, 3785.

8 [1975] NZLJ 605.

9 Above $\mathbf{n} 8$.

10 Atove $n 8$ (emphasis in original).

11 Electoral Amendment Act 1975. 
marginal seat, such as the Eden electorate which contains Mount Eden Prison, was avoided by the provision that inmates had to enrol and vote in the electorate in which they last resided. This necessitated their casting a special vote. ${ }^{12}$

With the fall of the Labour Government in 1975, the incoming National Government moved to repeal the provision which enabled prisoners to vote. The Electoral Amendment Act 1977 restored the wording of the original provision, namely that all persons "detained in any penal institution pursuant to a conviction"13 were disenfranchised. This remained the law until the Electoral Act 1993 which conferred the franchise on some prisoners.

\section{B Royal Commission's Recommendation on Prisoners' Right to Vote}

In its report, the Royal Commission considered, inter alia, whether prisoners should have the right to vote. ${ }^{14}$ It expressed the view that the law, as enacted in s 42(1)(d) of the Electoral Act 1956 which disqualified all prisoners "detained in any penal institution pursuant to a conviction" should be amended by enfranchising those prisoners who were serving a sentence of less than three years. ${ }^{15}$ The reason advanced by the Royal Commission in support of this time period was (somewhat inexplicably) based on the equating of prisoners' rights to those of "citizens absent overseas". ${ }^{16}$ This latter category lost the right to vote after a continuous absence overseas of three years under the 1956 Act. The Royal Commission saw an analogy between these two categories of persons and recommended that: ${ }^{17}$

Prisoners who following conviction have been sentenced to a term of 3 years or more should not be allowed to vote.

There can be little doubt that the reasoning of the Royal Commission in its brief discussion of this issue is seriously deficient from an international human rights perspective. Specifically, the Royal Commission does not refer to or consider New Zealand's international legal obligations under article 25 of the Covenant at any point in its report. This is a surprising and crucial omission. In the light of the international and Canadian

12 Auckland Star, 8 November 1975, p 1. Reported that all but 11 of the 300 inmates at Mount Eden enrolled to vote and that there was a $75 \%$ inmate enrolment at Paremoremo Maximum Security Prison.

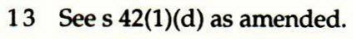

14 Above n 1, para 9.21 and recommendation 42.

15 Above n 1, para 9.21 and recommendation 42.

16 Above n 1, para 9.21 and recommendation 42.

17 Above $n$ 1, recommendation 42. 
case law, it is clearly arguable that the Royal Commission's recommendation on prisoners' right to vote is flawed and contrary to New Zealand's obligations under article 25 of the Covenant. ${ }^{18}$

\section{Implications of the Bill of Rights Act on Prisoners' Right to Vote: The Solicitor- General's Opinion on Proposed Changes to the Electoral Act}

In 1992, when the Electoral Act 1993 was being drafted the issue of prisoner disenfranchisement was revisited in the light of the Bill of Rights Act. The Department of Justice sought an opinion from the Solicitor-General to ascertain whether inclusion of a provision identical to the existing provision in s 42(1)(d) of the Electoral Act 1956 would be consistent with s 12(a) of the Bill of Rights Act, and if inconsistent, whether such provision could be said to comply with $\mathbf{s} 5$ of the Bill of Rights Act. Section 5 provides that the rights and freedoms in the Bill of Rights Act:

may be subject only to such reasonable limits prescribed by law as can be demonstrably justified in a free and democratic society.

The Solicitor-General wrote an extensive opinion. ${ }^{19}$ The Solicitor-General was in no doubt that an identical provision to $\mathrm{42}(1)(\mathrm{d})$, which had the effect of disenfranchising all prisoners, would represent a prima facie breach of s 12(a). In fact, he considered the matter to be "clear beyond argument". 20

Having established that a prima facie breach would occur if the provision remained unchanged, the balance of the Solicitor-General's opinion turned to the question whether the breach could be said to be a justified limitation in terms of $\mathrm{s} 5$.

In addressing the issue of whether the breach constituted a justified limit in terms of s 5 , the Solicitor-General canvassed Canadian Charter jurisprudence. While acknowledging that a clear majority of the lower court decisions had held that the equivalent Canadian provision was not a justified limitation, the Solicitor-General was of the opinion that the Canadian cases would not provide much assistance with the matter yet to be decided by the Supreme Court of Canada. ${ }^{21}$ The Solicitor-General derived limited assistance from the two

18 See generally JB Elkind and A Shaw A Standard for Justice: A Critical Commentary on the Proposed Bill of Rights for New Zealand (Oxford University Press, Auckland, 1986) 46-48.

19 This opinion was obtained by the author from the Crown Law Office after a decision by that Office to waive professional privilege in relation to it. It has not been previously released or commented upon. Text reproduced in Appendix B of the author's LLM thesis.

20 Solicitor-General's Opinion JUS 043/73, 17 November 1992, 2.

21 Above $n$ 20, 3. 
appellate decisions he cited as they took opposite views. In $\operatorname{Re~Badger}^{22}$ the Manitoba Court of Appeal had upheld the limit as a justifiable one in terms of $\mathbf{s} 1$ of the Charter. The Federal Court of Appeal in Belczowski $v$ The Queen, ${ }^{23}$ on the other hand, had held that the interference with the right to vote was not a reasonable limitation that was justified pursuant to 1 of the Charter. ${ }^{24}$

A deficiency in the Solicitor-General's opinion is that it failed to note that Belczowski had been followed by another appellate Court in March 1992, eight months prior to the date of the Solicitor-General's opinion. In Sauvé $v$ Attorney-General of Canada ${ }^{25}$ the Ontario Court of Appeal had held that s 51(e) of the Canada Elections Act - the equivalent provision of s 42 (1)(d) - was of no force and effect. Both Belczowski and Sauvé were subsequently upheld by a full bench of nine Judges of the Supreme Court of Canada. It should also be noted that the Solicitor-General, like the Royal Commission before him, fails to consider the implications of New Zealand's treaty obligations under article 25 of the Covenant.

In assessing s 5 issues under the Bill of Rights Act 1990, the Solicitor-General applied the well-known Oakes ${ }^{26}$ test as expressed by Richardson $\mathrm{J}$ in Noort ${ }^{27}$ in the following language:

1) the significance in the particular case of the values underlying the Bill of Rights Act;

2) the importance in the public interest of the intrusion on the particular right protected by the Bill of Rights Act;

3) the limits sought to be placed on the application of the Act provision in the particular case; and

4) the effectiveness of the intrusion in protecting the interests put forward to justify those limits.

Applying this test, the Solicitor-General concluded that s 42(1)(d) did not meet these criteria and thus could not be saved by 5 .

22 (1988) 55 DLR (4th) 177.

23 (1992) 90 DLR (4th) 330.

24 Above n 23, 344.

25 (1992) 89 DLR (4th) 644.

26 (1986) 26 DLR (4th) 200.

27 Ministry of Transport $v$ Noort; Police $v$ Curran [1992] 3 NZLR 260, 284; see also, R $v B$ [1995] 2 NZLR 172, 183. 
The opinion then turned to the question of ensuring compliance with the Bill of Rights Act. The reasoning of the Canadian cases that the practice of disenfranchising prisoners based on the length of sentence is arbitrary was noted. ${ }^{28}$ The Solicitor-General, however, decided to follow the Royal Commission's recommendation, and advised that disenfranchising prisoners who were serving a sentence of more than three years would satisfy $\mathbf{s} 5$ of the Bill of Rights Act. He found the logic presented by the Royal Commission to set the limit at three years "persuasive". ${ }^{29}$ However, the logic of the Royal Commission's recommendation, as previously suggested, is open to question. The Royal Commission drew a parallel between the rights of long-term prisoners and those citizens absent overseas. This seems an arbitrary analogy. Arbitrary because it is illogical to equate the position of longterm prisoners with that of citizens who choose to spend three years overseas.

The opinion of the Solicitor-General was accepted as the basis for the new electoral legislation. Section 80 (d) of the Electoral Act 1993 accordingly disqualifies from registration:

d) A person who, under-

i) A sentence of imprisonment for life; or

ii) A sentence of preventive detention; or

iii) A sentence of imprisonment for a term of 3 years or more,-

is being detained in a penal institution.

Although this is the law in New Zealand, it is submitted that this provision does not comply with New Zealand international treaty obligations or the Bill of Rights Act. ${ }^{30}$

\section{International Obligations}

The relevant obligations of article 25 binding on New Zealand are that:

Every citizen shall have the right and the opportunity, without any of the distinctions mentioned in article 2 and without unreasonable restrictions:

(b) To vote and to be elected at genuine periodic elections which shall be by universal and equal suffrage and shall be held by secret ballot, guaranteeing the free expression of the will of the electors;

28 Above n 20, 7.

29 Above n 20, 7.

30 The same view is expressed in Elkind and Shaw, above $n$ 18, 48. 
The critical points, for present purposes, are first that "[u]niversal suffrage requires that the broadest reasonable pool of voters is guaranteed participatory rights"; 31 and, secondly, that a state (in the words of article 25) may not impose "unreasonable restrictions" on the right to vote. The same starting point and orientation has been expressed as follows: ${ }^{32}$

Disqualifying factors must not represent impermissible discrimination and should be limited, so as to provide the maximum reasonable enfranchisement of the people.

The concept of "unreasonable restrictions" was considered by the Human Rights Committee in 1981 in Alba Pietraroia v Uruguay. ${ }^{33}$ In its Views, the Human Rights Committee expressly referred to the principle of proportionality, which it said is implicit in the notion of "unreasonable restrictions". Elaborating on this "concept of unreasonable restrictions" in Human Rights and Elections, it is said: ${ }^{34}$

Reasonable requirements are usually limited to minimum age, nationality and mental capacity. The work of the Human Rights Committee provides a good deal of guidance on the limits of reasonable restrictions. In the course of their deliberations, as mandated by the International Covenant on Civil and Political Rights, members of the Committee have noted that the following limitations on voting rights are not permissible:

a) economic requirements, based on receipt of public assistance, ownership of property, or income;

b) excessive residency requirements;

c) restrictions on voting by naturalized citizens;

d) language requirements;

e) literacy requirements;

f) excessive limitations on the voting rights of convicted criminals.

In addition, while limitations are allowed for persons convicted of electoral offences, such restrictions must be limited in time.

31 Centre for Human Rights, Human Rights and Elections, Professional Training Series No 2, HR/P/PT/2, United Nations New York and Geneva, 1994, 10, para 64.

32 Above n 31, 15, para 106.

33 Comm No 44/1979, Views of 27 March 1981. 1 Selected Decisions of the Human Rights Committee, 76, 79, para 16.

34 Above n 31, 10-11, para 65 (footnotes omitted). See also, Elkind and Shaw, above n 18, 48. 
It should also be noted that in $C F v$ Canad $a^{35}$ the Human Rights Committee observed that in 1979 the Quebec provincial government had enfranchised prisoners, "[i]n order to bring the Quebec Election Act into conformity with the provisions of article 25 of the Covenant". ${ }^{36}$

Neither the Royal Commission nor the Solicitor-General appears to have been aware of the implications of these obligations. Further, developments in Canada under the Charter reinforce what the correct approach ought to be.

\section{E Recent Canadian Case Law}

In Canada the Canadian Charter is supreme law. In 1993 the Attorney-General and Solicitor-General jointly appealed the decisions of Sauvé and Belczowski. A full bench of nine Judges of the Supreme Court heard the appeals and unanimously dismissed the appeals. In delivering the judgment of the Court Iacobucci J stated that: ${ }^{37}$

The Attorney General of Canada has properly conceded that s 51(e) of the Canada Elections Act, contravenes $\mathrm{s} 3$ of the Canadian Charter of Rights and Freedoms but submits that $\mathrm{s}$ 51(e) is saved under $s 1$ of the Charter. We do not agree. In our view, s 51(e) is drawn too broadly and fails to meet the proportionality test, particularly the minimal impairment component of the test, as expressed in the $\mathbf{s} 1$ jurisprudence of the Court.

In response to this judgment s 51(e) was amended so as to disqualify prisoners serving a sentence of two years or more from voting in a federal election. This amendment has in turn been successfully challenged on the basis that this new limit still did not comply with $\mathrm{s} 1$ of the Charter. In striking down the amendment provision Weston J of the Trial Division of the Federal Court, in a comprehensive judgment, did not specify what might constitute a "reasonable" limit, but did refer to an official government publication which stated with respect to 3 of the Charter that: ${ }^{38}$

The tradition of democratic rights in Canada is specifically guaranteed by the Charter. Citizens will have a constitutionally enshrined right to vote in elections... . The only restrictions that may be placed on your right to vote or run in an election will be those that are

35 CF $v$ Canada, Comm No 113/1981, Decision of 12 April 1985. 2 Selected Decisions of the Human Rights Committee under the Optional Protocol, 13, 13, para 3.1.

36 The case was declared inadmissible for failure to exhaust domestic remedies.

37 Sauvé v Canada (Attorney General) [1993] 2 SCR 438, 439-440.

38 (1995) 132 DLR (4th) 136, citing The Charter of Rights and Freedoms: A Guide for Canadians (Ottawa, Ontario, 1982) 6. 
considered to be reasonable and justified, such as the age restriction for minors, mental incompetence, and certain restrictions on some election of officials.

A full consideration of Weston J's extensive judgment is beyond the scope of this article, but the following key points are noted:

1 It was accepted that a rational connection exists between disenfranchisement and enhancement of civic responsibility and respect for the rule of law. However the punitive component of $s 51(\mathrm{e})$ - even as amended - meant that the section failed the minimum impairment test.

2 An alternative process for court-imposed disqualification on a case-by-case basis by the sentencing judge, would be both less intrusive and satisfy the government's legitimate objectives. This was held to be "to disqualify only those types of offenders whose indecency is so profound as to threaten the principles of a free and democratic society".

3 In RJR-McDonald $v$ Canada ${ }^{39}$ the Supreme Court considered and elaborated on the approach to $s$ of the Charter, as first set out in $R v$ Oakes. ${ }^{40}$ McLachlin J noted that: ${ }^{41}$

The question is not whether the measure is popular or accords with the current public opinion polls. The question is rather whether it can be justified by application of the processes of reason... . The process is not one of mere intuition, nor is it one of deference to Parliament's choice. It is a process of demonstration. This reinforces the notion, inherent in the word "reasonable" of rational inference from evidence or established truths.

4 The judgment contains an anthology of expert opinion of political theorists on the significance of the franchise. The need for wide consideration of the issue is reflected by Weston J when he stated:42

Given the issues in this case, the type of expert evidence adduced represents a most reasonable approach to assisting the court in its determination as to whether the disenfranchisement of prisoners is justified.

39 (1995) 127 DLR (4th) 1.

40 Above $n 26$.

41 Above n 39, 89 (emphasis in original), cited in Sauvé v Canada, above n 38.

42 Above $n 38$. 
5 The dearth of scholarship addressing the question of prisoner disenfranchisement is illustrated by Weston $\mathrm{J}$ when he points out: ${ }^{43}$

other than John Stuart Mill in a brief footnote reference, no well-known political theorist or moral philosopher, including de Tocqueville, Kant, Locke, Rousseau, or Hobbes, has ever considered the question. More recent political and philosophers, such as Rawls, Hart, Murphy, and Morris, have also not specifically considered this issue.

The Canadian decisions overall illustrate the complexities of the issue of prisoner enfranchisement. They highlight the principle of proportionality. They highlight the arbitrary nature of setting a disqualification limit based simply on the length of custodial sentence. In this regard, proposition number two above, has great force and relevance to New Zealand obligations under article 25. Proposition two, which would impose a decision on a case-by-case basis at sentencing, seems to be consonant with the notion of "unreasonable restrictions" and with the principle of proportionality which is a central feature of the jurisprudence of the Human Rights Committee. Such an approach would help achieve "the maximum reasonable enfranchisement of the people" and focus attention on the nature of the crime rather than the sentence imposed.

\section{F New Zealand Bill of Rights Act 1990}

The limitations of the Bill of Rights Act 1990 and the potential implications of New Zealand's legal obligations under article 25 of the Covenant are well illustrated in the case of Re Bennett. ${ }^{44} \mathrm{Mr}$ Bennett, a prisoner, wished to vote in the 1993 general election. He made an application to the High Court to determine his right to vote under s 12(a) of the Bill of Rights Act. The application was dismissed on the grounds that there was a clear conflict between the provision of s 42(1)(d) of the Electoral Act 1956 and s 12(a) of the Bill of Rights Act. The court held that in light of s 4 of the Bill of Rights Act the Electoral Act disqualification must prevail. However, while Greig J stated that "this conflict is so plain as to give no room for any argument", 45 he nonetheless acknowledged that Bennett may have had a right to apply to the Human Rights Committee in relation to an alleged breach of article 25(a) of the Covenant but said, "it is not a right that I can be concerned about or can deal with in the Court."46

\footnotetext{
43 Above $\mathrm{n} 38$.

44 Above $n 2$.

45 Above n 2, 361.

46 Above n 2, 361.
} 


\section{G Summary}

The Canadian courts have been dealing with the issue of prisoner voting for a number of years and the law has developed on a case-by-case basis. The New Zealand SolicitorGeneral considers s 80(d) of the Electoral Act 1993 satisfies the Bill of Rights Act, but this opinion warrants further debate, especially in the light of New Zealand's international obligations under article 25 of the Covenant and the recent Canadian case law. In contrast to the breadth of discussion in the Canadian decisions, the issue of prisoner enfranchisement in the Royal Commission report amounted to under two pages and did not consider or refer to New Zealand's international obligations under article 25 of the Covenant.

The international and Canadian jurisprudence must mean that the New Zealand restriction on prisoners' voting in s 80(d) of the Electoral Act 1993 is contrary to the Bill of Rights Act and New Zealand's international obligations under article 25 of the Covenant.

\section{CITIZENS' RESIDENTIAL REQUIREMENTS FOR VOTING}

Section 39 of the Electoral Act 1956 provided that every adult person was qualified to be registered as an elector of an electoral district if -

a) He is a British subject; and

b) He is ordinarily resident in New Zealand; and

c) He has at some period resided continuously in New Zealand for not less than one year; and either...

"Ordinarily resident in New Zealand"47 was defined in s 38 of the Act as those -

a) ....actually residing in New Zealand with the intention of residing therein indefinitely; or

b) Having been actually resident in New Zealand with the intention of residing therein indefinitely, ... is outside New Zealand...Provided that any person...who has been outside New Zealand continuously for more than three years shall be deemed not to be ordinarily resident in New Zealand.

Section 80(a) and (b) of the Electoral Act 1993 disqualifies for registration as electors:

a) A New Zealand citizen who ... is outside New Zealand and has not been in New Zealand within the last 3 years:

47 The meaning of "ordinarily resident" and its relation to art 25 of the Covenant was considered in the Hong Kong case $R v$ Apollonia Liu, ex parte Lau San-ching (1995) High Ct MP No 3215 of 1994 Cheung J, 22 Feb 1995. (1995) 3 [Hong Kong] Bill of Rights Bulletin 38, 39. 
b) A permanent resident of New Zealand ... is outside New Zealand and has not been in New Zealand within the last 12 months.

Does New Zealand law comply with article 25 of the Covenant and s 12(a) of the Bill of Rights Act? Is a 3 year limit a disproportionate restriction? It is strongly submitted that the New Zealand provisions do not comply.

The Royal Commission report did not consider New Zealand's international obligations under the Covenant in relation to this issue but nonetheless concluded (referring to the 1956 provisions) that "the present provisions are generous". 48 Section 80 (a) and (b) of the Electoral Act 1993 reflect this conclusion. This issue should have been looked at in the light of New Zealand's international legal obligations. It also needs to be looked at independently of the question of the right to vote of permanent residents. The issue must be considered in terms of the principle of proportionality. The main argument in favour of a residential requirement is based on the belief that there should be a sufficient connection between the voter and the state, additional to citizenship or permanent residence alone. ${ }^{49}$ The law as it has stood in New Zealand since 1956 adopts a three-year-consecutiveabsence rule. It is extremely doubtful that this rule can be said to comply with the principle of proportionality. In Canada the eligibility criteria for citizens who reside overseas is more generous. The equivalent Canadian provision adopts a five-year-consecutive-absence rule: $:^{50}$

Any of the following persons may vote ...

d) a person who has been absent from Canada for less than five consecutive years and who intends to return to Canada as a resident;

The world has changed significantly as a result of the mass communications revolution. In today's world, it is relatively easy for a citizen to maintain a strong link and connection with the state despite being absent from the state for a considerable length of time. With the advent of the fax and the internet, it comparatively easy for a citizen residing overseas to maintain regular, detailed and quality contact with events and happenings in New Zealand. This is not the case for prisoners. In terms of New Zealand's international obligations, the principle of proportionality and s 12(a) (and s 5) of the Bill of Rights Act, the disqualification rule should apply only after a period of five consecutive years' absence enabling more citizens to vote in at least one election while overseas. Time spent absent

48 Above n 1, 233, para 9.7.

49 Above n 1, 233, para 9.7.

50 Section 51.1, Canada Elections Act 1973. 
from New Zealand should not be the only consideration in imposing a residence requirement limit. As noted in $R v$ Apollonia Liu, ex parte Lau San-ching a residence requirement may serve a number of legitimate purposes. These include: ${ }^{51}$

a) ensuring the integrity of the electoral process;

b) ensuring that voters are properly informed of the issues in any election; and

c) ensuring that voters [and candidates] have a sufficient connection with the territory.

And, as the court stressed in that case, there must be a rational basis for imposing any requirement on election rights, and any such requirement must not be disproportionate to achieve the legitimate aim of imposing a residential requirement. 52

\section{GENUINE ELECTIONS}

\section{A International Obligations}

One of the important aspects of $s$ 12(a) of the Bill of Rights Act is that it provides for the right to vote in "genuine" periodic elections. This language is drawn from the International Covenant on Civil and Political Rights and the Universal Declaration of Human Rights, both of which provide that elections must be "genuine". 53

As the word "genuine" is absent from the equivalent Canadian Charter provision there is no Canadian jurisprudence. There is, however, a commentary in Human Rights and Elections ${ }^{54}$ which provides guidance on the pragmatic aspects required of a "genuine" election. The commentary identifies six aspects of a "genuine" election. These are:55
i) Genuine procedures;
ii) Genuine effects;
iii) A real choice;
iv) Equal access to public service;
v) An informed choice; and
vi) Legal and technical issues.

51 Above $\mathbf{4 7}$.

52 Above n 47, 40.

53 Covenant, art 25(b)("genuine periodic elections"); Universal Declaration of Human Rights, art 21 ("genuine elections").

54 Above $\mathbf{n} 31$.

55 Above n 31, 12-14, paras 76-93. 
The travaux préparatoires of the Covenant indicate that the drafters saw the concept of "elections being genuine" as requiring the presence of two broad elements. The first being "procedural, and included the guarantees of periodicity, equality and universality of suffrage, and secrecy of the ballot". 56 The second, and the focus of this discussion, was "outcome-oriented" and defined genuine elections as those "which reflected the free expression of the will of the electors". 57

Having established that genuine elections are those which give effect to the freely expressed will of the people the handbook notes that genuine elections are those which also offer "an actual choice to the electorate". 58

It is this aspect of a genuine election which is used here to measure whether the introduction of a closed list and the ability of a candidate to stand in both a constituency and on the party list under the MMP system precludes an actual choice in a genuine election. A closed list is a list that cannot be changed by voters; there is no provision to register a negative vote against people on the list. While it is not a closed list per se that removes choice it is the fact that it provides an avenue which enables a candidate rejected by a constituency to enter Parliament. Further, as will be discussed later, the legislation permits a member elected via the party vote to leave that party for another thus altering the proportionality of Parliament.

While not containing the word "genuine", article 3 of Protocol No 1 of the European Convention on Human Rights does provide for elections to be held "under conditions which will ensure the free expression of the opinion of the people in the choice of the legislature". Judicial considerations of article 3 have held that while the right to vote is guaranteed it may be qualified. Nevertheless, the European Court of Human Rights has held that each institution must satisfy themselves that "the conditions do not curtail the rights in question to such an extent as to impair their very essence and deprive them of their effectiveness". 59 While there is scope for national variations, any conditions must have a legitimate aim and reflect the democratic ideal of "the free expression of the opinion of the people in the choice of the legislature" as the core concept. ${ }^{60}$

56 Above n 31, 12, para 76.

57 Above n 31, 12 para 76 (footnote omitted).

58 Above n 31, 12 para 79.

59 Mathieu-Mohin and Clerfayt $v$ Belguim (1987) 10 EHRR 1, 16, para 52. See also AH Robertson and JG Merrills Human Rights in Europe. A Study of the European Convention on Human Rights (3ed, Manchester University Press, Manchester, 1993) 226.

60 Robertson and Merrills, above n 59, 226. 
The introduction of a closed list and the ability of a candidate to stand in both a constituency and on the list under MMP means that the New Zealand voter has lost the ability to vote a candidate out of office in an electorate. This raises the issue whether such election can be said to be "genuine" within the meaning of the Universal Declaration of Human Rights, the Covenant and the Bill of Rights Act. This issue was not directly considered by the Royal Commission.

A fundamental aspect of the Westminster system was the ability of an electorate to reject individual candidates, and collectively, a government. MMP diminishes the power of the franchise by enabling candidates to escape the impact of voter choice. In the system of MMP which operates in New Zealand a candidate can stand in a constituency and lose, but still become a Member of Parliament by being sufficiently high on the party list. Further, once elected as a party list candidate the Member may leave that party and join another or remain an independent Member for the duration of the term of Parliament. The actual choice of the wider electorate who voted for that particular party is further diminished because the proportional aspect of that party's list votes are no longer representative of their Members in Parliament. This outcome clearly fails two aspects of the standard for defining a "genuine" election. The will of the electors is disregarded and the actual choice to the electorate is reduced because the list candidate is able to avoid the consequences of the constituency vote.

To restore an actual choice to the New Zealand electorate, the law should be changed to make it clear that candidates are able to stand only as either a list or as a constituency candidate. Moreover, the list should be able to reflect voter disapproval by being open, enabling a negative vote to be registered. If a candidate elected as a result of the list vote leaves the party then they should be replaced by the next name on the list in order to preserve the will of the electors. Alternatively, if the list is to remain closed then the significance of the franchise could be enhanced by providing that no person may be a list MP for more than two terms. This would restore a level of accountability to the electorate since to continue in parliament after two terms the candidate must test their relationship with an electorate. The present system needs to be revisited in the light of New Zealand's obligations under article 25 and s 12(a) of the Bill of Rights Act.

\section{B Human Rights Committee Draft General Comment on Article 25}

Periodically the Human Rights Committee issues general comments to the State Parties to the Covenant. The general comments are designed to assist State Parties in the further 
implementation of their obligations under the Covenant. The legal status of the general comments derives from article $40(4)$ of the Covenant which provides:

The Committee shall study the reports submitted by the States parties to the present Covenant. It shall transmit its reports, and such general comments as it may consider appropriate, to the States Parties...

The general comments, which are updated from time to time, form a body of jurisprudence to provide an authoritative legal interpretation of Covenant obligations. They are frequently relied on and cited by the Human Rights Committee when adopting its "views" in relation to communications submitted by individuals under the Optional Protocol to the Covenant. ${ }^{61}$

At the present time the Human Rights Committee is in the process of drafting a general comment on article 25. Dealing with the election process, the intention of the draft general comment was "that people should be able to exercise real and effective electoral options in an atmosphere of free choice". 62 Meeting in October 1995, the Human Rights Committee had before it for discussion the following draft general comment dealing with, inter alia, the meaning of "genuine ...elections": 33

For elections to be genuine in conformity with subparagraph (b), they must be conducted fairly and freely on a periodic basis within a framework of laws guaranteeing citizens' rights and enabling them to be enforced. They should be held in respect of bodies which have full responsibility for the exercise of legislative and/or executive power and at intervals which respect the right of citizens to choose freely their representatives. Citizens must be free to vote for any candidate for election and for or against any proposal submitted to referendum or plebiscite, and free to support or oppose government, without undue influence or coercion of any kind which may distort or inhibit the free expression of the electors will. Voters should be able to form opinions independently, free of violence or threat of violence, compulsion or manipulative interference of any kind; they should have access to unimpaired campaign advertising. However, unrestrained spending on election campaigns may unduly favour the

61 For example Eric Hammel $v$ Madagascar, Comm No 155.1983, Views of 3 April 1987, 2 Selected Decisions of the Human Rights Committee under the Optional Protocol 179, 182, para 19.2 (referring to General Comment 15(27)); Albert Berry v Jamaica, Comm No. 330/1988, Views of 7 April 1994, UN Doc. CCPR/C/50/D/330/1988 (26 April 1994).

63 Above n 62, para 58. For earlier discussions, see CCPR/C/SR. 1385 (18 November 1994); CCPR/C/SR.1399 (10 April 1995); CCPR/C/SR.1414/Add.1 (9 May 1995). At the time of writing, the Human Rights Committee's discussions of April 1996 are not yet available. 
wealthy and distort or undermine the free choice of citizens. The results of genuine elections should be respected and implemented, whether or not they favour the maintenance or transfer of power.

The significance of these draft general comments is that they emphasise a citizen's right to chose freely his or her representatives and to support or oppose government. The spirit of article 25 of the Covenant (and s 12(a) of the Bill of Rights Act) is to lay emphasis on the rights of the individual voter. Political parties are not specifically mentioned. This approach of the Human Rights Committee is in contrast to the Royal Commission which focuses on the importance of political parties. Thus, under the MMP system favoured by the Royal Commission: ${ }^{64}$

List members would be elected from ordered party lists nominated by each registered political party prior to election day. Since the list vote is a choice between alternative party governments it would be impracticable to allow independent candidates to appear on the list section of the ballot. Voters would not be able to alter the order of candidates on a party's list and the ballot paper would only need to show each party's name and the first few names on each party's list. Parties could include constituency candidates on their lists. Candidates elected in a constituency would be deleted from the party's list.

As previously noted, the Royal Commission report failed to consider New Zealand legal obligations in relation to article 25 of the Covenant. The Report contains no consideration of what constitutes a "genuine" election. It is submitted that the electoral system of MMP recommended by the Royal Commission and subsequently adopted in the Electoral Act 1993 is contrary to article 25 of the Covenant and to s 12(a) of the Bill of Rights Act in that closed party lists remove actual choice from the individual voter and therefore, are contrary to the requirement of a "genuine" election.

\section{CONCLUSION}

The aspects of New Zealand electoral law examined in this article show a disturbing lack of consideration of New Zealand's international treaty obligations and to the requirements of the New Zealand Bill of Rights Act. A number of the statutory provisions which have been examined are, on analysis, found to be in violation of relevant treaty and Bill of Rights Act norms and requirements. Specifically and fundamentally, they are contrary to the principle of proportionality.

It appears that neither the Royal Commission, the Solicitor-General or those responsible for the drafting of the Electoral Act 1993 gave proper consideration to the implications of

64 Above n 1, 43, para 2.116 (c). 
New Zealand's obligations under the International Covenant of Civil and Political Rights, to article 25 in particular, or to the combined requirements of $s$ 12(a) and s 5 of the Bill of Rights Act 1990.

Under article 25 of the Covenant a state may not impose "unreasonable restrictions" on the right to vote. This right is to be approached on the footing that a state provide "the maximum reasonable enfranchisement of the people". On this basis, prisoners have, in principle, the right to vote subject only to "reasonable restrictions" imposed by the state. In assessing the concept of "unreasonable restrictions", the Human Rights Committee has held that the principle of proportionality is implicit in the notion of "unreasonable restrictions".

The conclusion therefore is threefold:

1 The present three-year-sentence-rule of s 80(d) of the Electoral Act 1993 is arbitrary and fails to meet the principle of proportionality. ${ }^{65}$ On the basis of Canadian case law, it is suggested that it is more consonant with the notion of "unreasonable restrictions" and the principle of proportionality to require a decision on a case-by-case basis and place greater weight on "the maximum reasonable enfranchisement of the people" and on the nature of the crime rather than the sentence imposed.

2 New Zealand law relating to the right to vote of citizens who are continuously absent overseas for a period of time is also arguably contrary to New Zealand's international obligations. The present law disqualifies a citizen who "has not been in New Zealand within the last 3 years". In today's world of mass communications, it is extremely doubtful that this rule could be regarded as complying with the principle of proportionality. The disqualification rule should only apply after a period of five consecutive years' absence. This would enable more citizens to vote in at least one election while overseas.

3 The introduction of a closed list in the Electoral Act 1993 means that the New Zealand voter has lost the ability to vote a candidate out of office in an electorate. The electoral system of MMP recommended by the Royal Commission and subsequently adopted in the Electoral Act 1993 is contrary to article 25 of the Covenant and to s 12(a) of the Bill of Rights Act 1990. Closed party lists remove actual choice from the individual voter and, therefore, are contrary to the requirement of a "genuine" election. To restore an actual choice to the New Zealand electorate, the law should be changed to make it clear that candidates are able to stand only as either a list or as a constituency candidate. 